\title{
The Family Knowledge about the Disease and Complications Risk among Diabetic Patients-in Poland
}

Anna Abramczyk*

Department of Nursing, Faculty of Medicine, University of Warmia and Mazury in Olsztyn, Poland

\begin{abstract}
Taking care of diabetic patients involves a family which is perceived as an environment, whose support is a factor that best forecasts implementation of required recommendations for diabetes care. The ability of family to support patients' effort can improve diabetes care results. The aim of this work is to indicate how family knowledge about the disease diversifies a medical condition and complications risk among diabetic patients. Research has been carried out within the scope of NCSR grant no. 6P05D02320, under the leadership of the work's author, among 1366 families/ caregivers of diabetic patients randomly chosen from 61 primary healthcare centres in Poland. For the purpose of this work, the research has been carried out based on: anonymous questionnaires among patients' families/caregivers, analysis of medical records.
\end{abstract}

Results: The majority of families supporting the patient have no knowledge about the disease $(56.2 \%)$. Among families with higher (moderate) knowledge level a statistical analysis demonstrated that the patient takes more care about oral hygiene $(p<0.00001)$, participates in self-control $(p<0.00001)$ and self-monitoring $(p<0.05)$, is more efficient and independent $(p<0.00001)$, have no somatic $(p<0.005)$ or psycho-emotional health complains $(p<0.005)$ or additional medical conditions $(p<0.005)$ and his/her weight $(p<0.0005)$ blood pressure $(p<0.005)$ and triglycerides level $(p<0.05)$ are in the normal range.

Conclusions: 1. Family knowledge about the disease is a significant factor that diversifies a medical condition of diabetic patients. 2. Higher knowledge level of the family about the disease improves patients' medical condition and reduces the risk of diabetes complications.

Keywords: Results of family knowledge; Diabetes; Risk of complications

\section{Introduction}

Diabetes is an issue of people around the globe [1]. Research shows that $8.3 \%$ of adults (over 170 million people) suffer from diabetes around the world $[2,3]$, and every 4 out of 5 patients live in the countries of low or average level of salary [4]. According to estimates, there are $8.4 \%$ adults (over 55 million people) [4] suffering from diabetes in the region of Europe, including over 3 millions in Poland (10.64\% of the adult population). Diabetes that lasts for years can lead to many complications in the cardiovascular system [5], retinopathy $[6]$, neuropathy $[6,7]$, renal insufficiency and even death $[7,8]$. Ischemic heart disease is the most frequent case of macroangiopathy and cause of death among people suffering from diabetes $[9,10]$. The risk of death due to heart diseases is 2-4 times higher in diabetes patients than in non-diabetes adults [10], with heath diseases causing around $65 \%$ of all deaths of people who suffer from diabetes $[9,11]$. Diabetes increases the risk of stroke by 2-8 times [12,13], and even 12 times if a patient suffers from arterial hypertension and diabetes at the same time [14]. On top of that, in Poland the mortality related to stroke is higher than in the USA and some countries of Western Europe [15]. Patients with a long history of diabetes make $8-10 \%$ of the group of people with poor vision or blind people [16]. Also, nephropathy is more frequent in diabetes patients than in the overall population [17]. Diabetes is the main cause of end-stage renal insufficiency in the USA, Japan and Europe [18-20]. The diabetes foot is another serious issue for the diabetics and leads to a greater risk of recurring ulcers, amputations and even death [21,22]. The rising mortality rate is also caused by diabetic neuropathy [23] which co-exists with other complications and is one of their preceding symptoms [24]. Studies show that over $80 \%$ of deaths related to diabetes occur in countries where salaries are low or average [25], with the risk of death being two or more times higher among people with diabetes
[26]. According to WHO, in 2030 diabetes will become the seventh most frequent cause of death worldwide [7]. The serious complications which increase the costs of health care, incidence of disabilities and early death among people suffering from diabetes make this disease one of the greatest challenges for the public health of the 21 st century $[3,4,27]$.

The relationship between the treatment of a chronic disease and the family situation requires that the provisioning of patient care is combined with involvement of the patient's family [28]. Patients and their families are the main parties burdened with and rendering care for chronic disease patients [28]. The care is more effective when the social environment of a patient (i.e. the family) supports his/her treatment $[28,29]$.

By rendering care the family provides emotional support, ensures the appropriate conditions of treatment, motivates the patient to stay healthy, performs nursing activities for the patient and helps him/her in the everyday duties $[29,30]$. In the case of diabetes patients, the family is a crucial factor impacting the regular implementation of medical recommendations for treatment of diabetes [29,31].

*Corresponding author: Anna Abramczyk, Department of Nursing, Faculty of Medicine, University of Warmia and Mazury in Olsztyn, Poland, Tel: +48 8952461 01; Fax: +48 8952461 14; E-mail: wesola2000@2com.pl

Received July 25, 2013; Accepted Spetember 29, 2013; Published October 04, 2013

Citation: Abramczyk A (2013) The Family Knowledge about the Disease and Complications Risk among Diabetic Patients-in Poland. J Data Mining Genomics Proteomics 4: 142. doi:10.4172/2153-0602.1000142

Copyright: $\odot 2013$ Abramczyk A. This is an open-access article distributed unde the terms of the Creative Commons Attribution License, which permits unrestricted use, distribution, and reproduction in any medium, provided the original author and source are credited. 
If prepared and trained properly, the patients, their families and friends could provide the right environment for administration of hypoglycaemic drugs and ensure the right time of administration (drugs vs. meals) in order to avoid errors in patient care [32].

If the family is not prepared appropriately to support the chronically ill patient, many adverse implications, including health risks for the patient could occur. Negative consequences of errors in drug administration, such as intensified risk of complications, increased incidence of diseases, physical disability and even death [33-36], put special focus on education and collaboration of health care professionals with respect to patients and their caregivers alike, because it will improve the competences in the area of chronic disease management $[33,37,38]$.

The aim of this work is to indicate how family knowledge about the disease diversifies a medical condition and complications risk among diabetic patients.

\section{Materials and Methods}

The 2001-2004 research project was aimed at identifying the condition of the primary health care in Poland related to diabetes patients.

One of the objectives was to verify the connection between the knowledge of diabetes among families and the risk of complications among people suffering from diabetes.

The study method, population sampling and the study toolkit (original questionnaires tested in prior pilot runs) were approved by the Committee for Scientific Research (KBN) in Warsaw and the Commission of Bioethics of Medical University (UM) in Wrocław.

The study uses a random sample to ensure that conclusions apply to the overall population of diabetics in terms of the primary health care [39]. As the population is very diversified in terms of the studies variables, such as the place of residence (cities, villages), and because there is no reliable sampling frame, the sample was selected using the stratified sampling method. The stratified sampling was chosen also because of the financial cost of the study [40]. The population of diabetics was divided into certain groups from which a certain number of elements were sampled. Every subject in the population belonged to one group only [39]. Based on the register of diabetes-related PHC and outpatient service providers and the administrative structure of Poland (16 provinces), the following were sampled in every province:

\section{1 district with a diabetes clinic;}

\section{1 district with no diabetes clinic;}

\section{Next, the following was sampled}

1 PHC facility in the capital of every province (16 facilities in total);

$1 \mathrm{PHC}$ facility in the district-level town in a district with a diabetes clinic, and 1 PHC facility in a rural area of that district (Tables 1 and 2).

Because of certain choice of services contracted by diabetes outpatient clinics and due to the nature of the administrative structure of Poland, in the provinces of Pomorskie, Śląskie there were less than 5 PHC facilities that qualified to the sample in line with the sampling criteria (Table 1). There were teams consisting of one family doctor and one family nurse deployed in 77 PHC facilities in Poland. If one team resigned, another team was prepared in the next PHC facility selected randomly. Since not all the facilities which declared to co-operate submitted study materials, the subsequent analysis covered the data

\begin{tabular}{|l|c|c|c|}
\hline Provence & $\begin{array}{c}\text { Number of } \\
\text { selected facilities } \\
\text { in every province }\end{array}$ & $\begin{array}{c}\text { Number of } \\
\text { facilities which } \\
\text { submitted study } \\
\text { materials }\end{array}$ & $\begin{array}{c}\text { Number of } \\
\text { facilities which } \\
\text { did not submit } \\
\text { study materials }\end{array}$ \\
\hline Dolnośląskie & 5 & 3 & 2 \\
\hline Kujawsko-pomorskie & 5 & 4 & 1 \\
\hline Lubelskie & 5 & 4 & 1 \\
\hline Lubuskie & 5 & 3 & 2 \\
\hline Łódzkie & 5 & 4 & 1 \\
\hline Małopolskie & 5 & 4 & 1 \\
\hline Mazowieckie & 5 & 4 & 0 \\
\hline Opolskie & 5 & 5 & 2 \\
\hline Podkarpackie & 5 & 3 & 0 \\
\hline Podlaskie & 5 & 5 & 1 \\
\hline Pomorskie **) & 3 & 2 & 1 \\
\hline Śląskie *) & 4 & 4 & 1 \\
\hline Świętokrzyskie & 5 & 4 & 16 \\
\hline Warmińsko- & 5 & 4 & 1 \\
\hline mazurskie & 5 & 4 & 1 \\
\hline Wielkopolskie & 5 & 4 & 1 \\
\hline Zachodniopomorskie & 77 & & 1 \\
\hline Total & 5 & & 1 \\
\hline (no & 5 & & 1 \\
\hline
\end{tabular}

*) no rural area in the district with no diabetes clinic

${ }^{* *}$ ) no district without a diabetes clinic

Table 1: Primary health care facilities selected for the study (province level).

\begin{tabular}{|l|l|l|l|l|l|l|l|}
\hline \multirow{2}{*}{ Studied area } & \multicolumn{3}{l|l|}{ PHC facilities } & \multicolumn{3}{l|}{$\begin{array}{l}\text { Study materials } \\
\text { submitted }\end{array}$} & \multicolumn{2}{l|}{$\begin{array}{l}\text { Study materials } \\
\text { not submitted }\end{array}$} \\
\cline { 2 - 9 } & N & $\%$ & N & $\%$ & N & $\%$ \\
\hline Capital of a province & 16 & 100 & 13 & 81.2 & 3 & 18.8 \\
\hline $\begin{array}{l}\text { District-level town in a } \\
\text { district with a diabetes clinic }\end{array}$ & 16 & 100 & 14 & 87.5 & 2 & 12.5 \\
\hline $\begin{array}{l}\text { Village in a district with a } \\
\text { diabetes clinic }\end{array}$ & 16 & 100 & 13 & 81.2 & 3 & 18.8 \\
\hline $\begin{array}{l}\text { District-level town in a } \\
\text { district with no diabetes clinic }\end{array}$ & 15 & 100 & 10 & 66.6 & 5 & 33.4 \\
\hline $\begin{array}{l}\text { Village in a district with no } \\
\text { diabetes clinic }\end{array}$ & 14 & 100 & 11 & 78.6 & 3 & 21.4 \\
\hline Total & 77 & 100 & 61 & 79.2 & 16 & 20.8 \\
\hline
\end{tabular}

Table 2: Studied area.

\begin{tabular}{|l|l|l|l|l|l|l|l|}
\hline \multirow{2}{*}{ Studied area } & \multicolumn{2}{|l|}{$\begin{array}{l}\text { Study } \\
\text { covered }\end{array}$} & \multicolumn{2}{l|}{$\begin{array}{l}\text { Qualified to next } \\
\text { stage analysis }\end{array}$} & \multicolumn{2}{|l|}{$\begin{array}{l}\text { Not qualified to next } \\
\text { stage analysis* }\end{array}$} \\
\cline { 2 - 8 } & $\mathbf{N}$ & $\%$ & $\mathbf{N}$ & $\%$ & $\mathbf{N}$ & $\%$ \\
\hline Capital of a province & 498 & 22.6 & 438 & 22.0 & 60 & 27.6 \\
\hline $\begin{array}{l}\text { District-level town in a } \\
\text { district with a diabetes clinic }\end{array}$ & 526 & 23.9 & 484 & 24.4 & 42 & 19.4 \\
\hline $\begin{array}{l}\text { Village in a district with a } \\
\text { diabetes clinic }\end{array}$ & 419 & 19.0 & 351 & 17.7 & 68 & 31.3 \\
\hline $\begin{array}{l}\text { District-level town in a } \\
\text { district with no diabetes clinic }\end{array}$ & 343 & 15.6 & 317 & 16.0 & 26 & 12.0 \\
\hline $\begin{array}{l}\text { Village in a district with no } \\
\text { diabetes clinic }\end{array}$ & 417 & 18.9 & 396 & 19.9 & 21 & 9.7 \\
\hline Total & 2203 & 100 & 1986 & 90.2 & 217 & 9.8 \\
\hline
\end{tabular}

*) As many pieces of data were missing, study materials from 217 patients have not been qualified for the next stage analysis.

Table 3: Study material classification for next stage analysis based on the studied areas.

from 61 facilities (Tables 1 and 2). The patient sample is mixed and derived from a closed population which was selected in a complex, multi-stage, stratified/cluster sampling [40,41]. The study covered all the patients who were registered with a given family doctor and a given family nurse in the respective PHC facility. The doctors, nurses, patients and their families participated in the study on a voluntary basis. For the 
purpose of this study, research was carried out among 1,366 families and care providers and among 1,986 patients with diabetes from 61 randomly chosen national primary health care service units, within the scope of NCSR grant no 6P05D02320, managed by the author of this work.

In the respective facilities, the study took up to 6 months but not less than 3 months. For the purpose of this work, the research was carried out on the basis of $[37,42-44]$ :

1. Nurse anamnesis (carried in the diabetes patient environment) including the following: patients knowledge on (questionnaire in Table 3): selected indices concerned with diabetes treatment (body mass, blood pressure, glycaemia, glucosuria, total blood cholesterol, hypoglycaemia), basic issues of diabetes treatment (causes of the disease, prevention of acute and chronic diabetes complications, diet, physical activity, feet hygiene, self- control, and diabetes pharmacotherapy) patients behavior, including: physical activity, alcohol, cigarettes, diet, feet care, whole body hygiene, mouth and teeth hygiene, treatment modifications within limits stated by the physician, taking drugs, contacting the GP, participation in laboratory examinations, feet and mouth observations, somatic complaints, and psycho-emotional disorders lasting over 2 weeks, factors that hinder fulfillment of the recommendations of diabetes treatment, care and nursing possibilities of the whole family of the patient, patient's social functioning (participation in family, marital, professional, and social life, as well as in social organizations), supply in agents and devices, that help in participation in the treatment and health care social situation of diabetes patients, social care, (family, neighbors), data based on the information concerning: ability of conversation, difficulties to gain help, sufficiency of help received, conformity of achieved help to the expectations, satisfaction of care level, living place, living conditions, marital status, education, sources of income, use of counselling and help: general practitioner, family, neighbors, social worker, specialist in outpatient diabetes clinic, patient's expectations as far as education and care: by general physician, health nurse, family, and social worker.

2. Nurse's assessment of diabetes patients abilities and selfdependence (relative assessment of fitness and independence of the patients);

3. Anonymous questionnaire, focused on obtaining patients' opinions on: access to medical services, satisfaction from health care, life, care;

4. Anonymous questionnaire among families giving support in the process of taking care of the patient, by which information upon knowledge about the disease, expectations and satisfaction from the care was obtained;

5. Analysis of the medical documentation. This included information provided by the GP (family doctor) as to: age, sex, type of diabetes, duration of illness, treatment methods, self-control, results from tests carried out within the previous 12 months (total cholesterol, cholesterol HDL, fasting glycaemia, glycosuria, microalbuminuria or proteinuria, creatinine, glycated haemoglobin, body mass, height, $\mathrm{BP}$, waist circumference, trochanters), accompanying diseases which require treatment.

The knowledge among families/caregivers of diabetes patients was assessed based on an anonymous questionnaire which contained a patient code (the questionnaires were submitted in envelopes by family nurses in charge of the patients) as well as open questions for longer answers and closed questions graded on a scale of 0 to 1 points.
The open question answers were evaluated based on several criteria graded as follows: full answer ( 1 point), incomplete answer ( 0.5 point), wrong answer (0 points), I don't know (0 points).

The total score for the knowledge was graded as follows:

1) optimal (20.5-23.0 points)

2) moderate (13.5-20.0 points)-some gaps in the knowledge

3) minimal (6.5-13.0 points)-many gaps in the knowledge

4) none (0-6 points)-lack of knowledge or numerous gaps

The answers were evaluated by the project manager and the author of this document. Characteristics of interest were described as frequencies and percentages and compared using the chi-square test [41]. All the tested hypotheses were verified at the level of significance of $\alpha=0.05$. Precise values of the significance level $p$ were calculated.

\section{Results}

Research materials were obtained from patients aged above 16 years, living in the area of work of a social and family nurse, and registered on the list of a local GP. The youngest patient was 17 and the oldest was 96. The majority of the tested population consisted of women (63.4\%), persons aged above $65(59 \%)$ and patients living in urban areas (57.7\%). The most numerous group of tested patients consisted of pensioners (49.5\%). Slightly more than one in three patients indicated disability pension as their source of income $(37.2 \%)$ and $9.3 \%$ of patients indicated a job on a farm as their source of income. The majority of persons interviewed were married (61.3\%). Almost every third patient was a widow or widower (30.3\%). Most of the patients took only oral drugs (56.8\%), every fifth patient took only insulin (20\%), and almost every fifth patient took insulin and oral drugs (18.5\%); only $4.7 \%$ of the patients were on a diet. Analysis of the medical documentation shows that diabetes type 1 was found in $11,6 \%$ of the patients and diabetes type 2 was found in $51.4 \%$, while $32.9 \%$ of the patients were treated without defining the type of diabetes. No information about diabetes type was found in the case of $4.1 \%$ of the patients. A pronounced majority of the patients were characterised by elementary or incomplete elementary education $(56.2 \%)$. Vocational education was found in $15.1 \%$ of the patients, secondary school education was found in $2.8 \%$, and higher education was found in $4 \%$ of the patients. No information about education was found in $0.9 \%$ of the patients.

Families supporting diabetics were surveyed for their knowledge on diabetes. The results show that the families usually do not know what the symptoms of ketotic coma are (86.2\%). More than every second person does not know: when to perform urine tests for acetone (84\%); what reduces the risk of complications in diabetes (79.9\%); what does glucagon cause (77.8\%); how to prevent hypoglycaemia (69.6\%) and hyperglycaemia (68.7\%); what promotes hypoglycaemia (66.5\%); what are the symptoms of hyperglycaemia $(64.3 \%)$; how to proceed in the case of hyperglycaemia (63.8\%); what are the potential complications in diabetes (57.1\%); what are the symptoms of hypoglycaemia $(54.1 \%)$; how to perform foot care in diabetes (52.3\%); what are the physical activity recommendations in diabetes $(51.8 \%)$; what the diabetes patient should control himself/herself (51.4\%). The families were most familiar with the drug indications in diabetes $(17.3 \%)$. The data is shown in Table 4 . The overall analysis of the knowledge about diabetes proves that it is below the optimal level (23-20.5 pts). 3.5\% of families demonstrated a moderate level of knowledge about diabetes (20.0-13.5 pts), and $43.9 \%$ had minimum knowledge only (13-6.5 pts). Every second caregiver (52.6\%) had no knowledge at all (6-0 pts). The analysis 


\begin{tabular}{|c|c|c|c|c|c|c|c|c|c|c|}
\hline \multirow[t]{3}{*}{ Provence } & \multicolumn{8}{|c|}{ The level of family's knowledge about the disease: } & \multirow{2}{*}{\multicolumn{2}{|c|}{ Total }} \\
\hline & \multicolumn{2}{|c|}{$\begin{array}{c}\text { Normal } \\
(23-20<\text { points })\end{array}$} & \multicolumn{2}{|c|}{$\begin{array}{c}\text { Moderate } \\
(20,0-13,5 \text { points })\end{array}$} & \multicolumn{2}{|c|}{$\begin{array}{c}\text { Minimal } \\
(13,0-6,5 \text { points })\end{array}$} & \multicolumn{2}{|c|}{$\begin{array}{c}\text { None } \\
(6-0 \text { points })\end{array}$} & & \\
\hline & $\mathrm{N}$ & $\%$ & $\mathrm{~N}$ & $\%$ & $\mathrm{~N}$ & $\%$ & $\mathrm{~N}$ & $\%$ & $\mathrm{~N}$ & $\%$ \\
\hline Lower Silesian (dolnośląskie) & 0 & $0.0 \%$ & 1 & $1.8 \%$ & 16 & $28.6 \%$ & 39 & $69.6 \%$ & 56 & $4.1 \%$ \\
\hline Kuyavian-Pomeranian (kujawsko-pomorskie) & 0 & $0.0 \%$ & 5 & $3.9 \%$ & 82 & $64.1 \%$ & 41 & $32.0 \%$ & 128 & $9.4 \%$ \\
\hline Lublin (lubelskie) & 0 & $0.0 \%$ & 5 & $5.1 \%$ & 38 & $38.4 \%$ & 56 & $56.6 \%$ & 99 & $7.2 \%$ \\
\hline Lubusz (lubuskie) & 0 & $0.0 \%$ & 1 & $3.2 \%$ & 8 & $25.8 \%$ & 22 & $71.0 \%$ & 31 & $2.3 \%$ \\
\hline Łódź (łódzkie) Lesser & 0 & $0.0 \%$ & 11 & $6.7 \%$ & 81 & $49.4 \%$ & 72 & $43.9 \%$ & 164 & $12.0 \%$ \\
\hline Poland (małopolskie) & 0 & $0.0 \%$ & 0 & $0.0 \%$ & 30 & $41.7 \%$ & 42 & $58.3 \%$ & 72 & $5.3 \%$ \\
\hline Masovian (mazowieckie) & 0 & $0.0 \%$ & 2 & $1.9 \%$ & 32 & $31.1 \%$ & 69 & $67.0 \%$ & 103 & $7.5 \%$ \\
\hline Opole (opolskie) & 0 & $0.0 \%$ & 6 & $5.1 \%$ & 62 & $53.0 \%$ & 49 & $41.9 \%$ & 117 & $8.6 \%$ \\
\hline Subcarpathian (podkarpackie) & 0 & $0.0 \%$ & 3 & $6.4 \%$ & 27 & $57.4 \%$ & 17 & $36.2 \%$ & 47 & $3.4 \%$ \\
\hline Podlaskie (podlaskie) & 0 & $0.0 \%$ & 3 & $3.4 \%$ & 26 & $29.2 \%$ & 60 & $67.4 \%$ & 89 & $6.5 \%$ \\
\hline Pomeranian (pomorskie) & 0 & $0.0 \%$ & 2 & $3.2 \%$ & 23 & $36.5 \%$ & 38 & $60.3 \%$ & 63 & $4.6 \%$ \\
\hline Silesian (śląskie) & 0 & $0.0 \%$ & 2 & $3.8 \%$ & 14 & $26.9 \%$ & 36 & $69.2 \%$ & 52 & $3.8 \%$ \\
\hline Świętokrzyskie (świętokrzyskie) & 0 & $0.0 \%$ & 1 & $1.1 \%$ & 54 & $58.7 \%$ & 37 & $40.2 \%$ & 92 & $6.7 \%$ \\
\hline Warmian-Masurian (warmińsko-mazurskie) & 0 & $0.0 \%$ & 3 & $3.1 \%$ & 42 & $43.3 \%$ & 52 & $53.6 \%$ & 97 & $7.1 \%$ \\
\hline Greater Poland (wielkopolskie) & 0 & $0.0 \%$ & 2 & $2.4 \%$ & 31 & $37.8 \%$ & 49 & $59.8 \%$ & 82 & $6.0 \%$ \\
\hline West Pomeranian (zachodniopomorskie) & 0 & $0.0 \%$ & 1 & $1.4 \%$ & 33 & $44.6 \%$ & 40 & $54.1 \%$ & 74 & $5.4 \%$ \\
\hline Total in Poland & 0 & $0.0 \%$ & 48 & $3.5 \%$ & 599 & $43.9 \%$ & 719 & $52.6 \%$ & 1366 & $100.0 \%$ \\
\hline
\end{tabular}

Table 4: Knowledge of the disease among diabetes patient families in specific provinces.

\begin{tabular}{|l|l|l|}
\hline The families do not know: & N & $\%$ \\
\hline What are the symptoms of ketoacidosis coma? & 1177 & $86.2 \%$ \\
\hline When to perform urine tests for acetone? & 1148 & $84.0 \%$ \\
\hline What reduces the risk of complications in diabetes? & 1092 & $79.9 \%$ \\
\hline What does glucagon cause? & 1063 & $77.8 \%$ \\
\hline How to prevent hypoglycemia? & 951 & $69.6 \%$ \\
\hline How to prevent hyperglycaemia? & 938 & $68.7 \%$ \\
\hline What promotes hypoglycemia? & 908 & $66.5 \%$ \\
\hline What are the symptoms of hyperglycemia? & 879 & $64.3 \%$ \\
\hline How to proceed in the case of hyperglycemia? & 871 & $63.8 \%$ \\
\hline What are the potential complications in diabetes? & 780 & $57.1 \%$ \\
\hline What is hypoglycemia? & 777 & $56.9 \%$ \\
\hline What are the symptoms of hypoglycemia? & 739 & $54.1 \%$ \\
\hline How to perform foot care in diabetes? & 714 & $52.3 \%$ \\
\hline What are the physical activity recommendations in diabetes? & 707 & $51.8 \%$ \\
\hline What the diabetes patient should control himself/herself? & 702 & $51.4 \%$ \\
\hline What favours hyperglycemia? & 651 & $47.7 \%$ \\
\hline What promotes normal glucose level in blood? & 645 & $47.2 \%$ \\
\hline What is the relationship between diabetes and the level of & 637 & $46.6 \%$ \\
\hline insulin? & & \\
\hline What is the aim of the diet (nourishment) in diabetes ? & 609 & $44.6 \%$ \\
\hline What the physical activity causes in diabetes? & 546 & $40 \%$ \\
\hline How to proceed in the case of hypoglycemia? & 541 & $39.6 \%$ \\
\hline How to perform nutrition in diabetes? & 467 & $34.2 \%$ \\
\hline What is the activity of the drugs in diabetes? & 237 & $17.3 \%$ \\
\hline Tab & & \\
\hline
\end{tabular}

Table 5: The insufficient level of knowledge about the fundamentals of diabetes treatment among the studied families which supported diabetes patients.

shows that a great majority of the families (96.1\%) which support diabetes patients does not have the sufficient knowledge about diabetes in order to support the patients effectively. The data is shown in Table 5.

According to statistics, the patients whose care giving families show moderate or minimum level of knowledge about the disease: have a higher (moderate) level of knowledge about the disease $(\mathrm{p}<0.00001)$, are familiar with indicators of one's health $(\mathrm{p}<0.00001)$, care for one's body $(\mathrm{p}<0.00001)$, mouth and teeth more $(\mathrm{p}<0.00001)$, exercise the expected measures of self-control $(\mathrm{p}<0.00001)$, monitor one's feet and mouth $(\mathrm{p}<0.05)$, physical activity $(\mathrm{p}<0.05)$, diet $(\mathrm{p}<0.00001)$ and foot care $(\mathrm{p}<0.00001)$. The data is shown in Tables 6 and 7 .

According to statistics, the patients whose care giving families show moderate or minimum level of knowledge about the disease more often have: the right body mass $(\mathrm{p}<0.0005)$, acceptable blood pressure $(\mathrm{p}<0.005)$, level of triglycerides $(\mathrm{p}<0.05)$, are physically fit $(\mathrm{p}<0.00001)$ and independent $(\mathrm{p}<0.00001)$, and lack other somatic $(\mathrm{p}<0.005)$ and mental symptoms $(\mathrm{p}<0.005)$ or other diseases which often accompany diabetes $(\mathrm{p}<0.005)$. The data is shown in Table 8 .

Furthermore, the patients who have families with good level of knowledge about the disease experience less problems with following the medical recommendations for treatment of diabetes $(\mathrm{p}<0.005)$, Also, they are more often have better social and living situation $(p<0.00001)$, and better access to medical services $(\mathrm{p}<0.05)$, while demonstrating less (moderate) demand for professional health care $(\mathrm{p}<0.00001)$ unlike patients who have families lacking the knowledge about diabetes. The data is shown in Table 9.

\section{Discussion}

A comprehensive summary is prevented due to the variety of tests, methods of assessing the knowledge, the type of the population and its size, and the studied areas $[45,46]$. Our results are hardly comparable with other studies which covered small populations of families of hospitalised patients, diabetic caregivers of children or patients suffering from a specific disease only [45-47]. Unlike results of other studies which show better knowledge among patients than their caregivers, in our study both patients and their caregivers had a similar level of knowledge about diabetes, however insufficient to ensure effective care. In our study, the level of the knowledge did not depend on the duration of the disease, unlike in the other studies [47].

The results confirmed the other studies in that the patients with better social status had families with higher knowledge of the disease [46]. Own studies revealed that families which have better knowledge of the disease promote various patient behaviours which are recommended for treatment of diabetes and help to keep the required indicators of health, such as: body mass, blood pressure, triglycerides, full physical 
Citation: Abramczyk A (2013) The Family Knowledge about the Disease and Complications Risk among Diabetic Patients-in Poland. J Data Mining Genomics Proteomics 4: 142. doi:10.4172/2153-0602.1000142

\begin{tabular}{|c|c|c|c|c|c|c|}
\hline \multirow{3}{*}{\begin{tabular}{|l} 
Tested feature \\
Total \\
$\mathrm{N}=1366$
\end{tabular}} & \multicolumn{6}{|c|}{ The level of family's knowledge about the disease: } \\
\hline & \multicolumn{2}{|c|}{$\begin{array}{c}\text { Moderate } \\
(20,0-13,5 \text { points }) \\
\mathrm{N}=48 \\
3,5 \%\end{array}$} & \multicolumn{2}{|c|}{$\begin{array}{c}\text { Minimal } \\
(13,0-6,5 \text { points }) \\
\mathrm{N}=599 \\
43,9 \%\end{array}$} & \multicolumn{2}{|c|}{$\begin{array}{c}\text { None } \\
\text { (6-0 points) } \\
\mathrm{N}=719 \\
52,6 \%\end{array}$} \\
\hline & $\mathbf{N}$ & $\%$ & $\mathbf{N}$ & $\%$ & $\mathbf{N}$ & $\%$ \\
\hline Knowledge (level) patients: & \multicolumn{6}{|c|}{ Chi^2 Pearsona: $338,307, d f=4, p<0,00001$} \\
\hline Moderate (20,0-13,5 points) & 18 & $29.5 \%$ & 35 & $57.4 \%$ & 8 & $13.1 \%$ \\
\hline Minimal (13,0-6,5 points) & 27 & $3.3 \%$ & 468 & $57.0 \%$ & 326 & $39.7 \%$ \\
\hline None (6-0 points) & 3 & $0.6 \%$ & 96 & $19.8 \%$ & 385 & $79.6 \%$ \\
\hline $\begin{array}{c}\text { Knowledge of health indicators (total cholesterol, fasting glycaemia, glycosuria, } \\
\text { body mass, blood pressure, hypoglycaemia): }\end{array}$ & \multicolumn{6}{|c|}{ Chi^2 Pearsona: $86,6325, d f=6, p<0,00001$} \\
\hline Knows all 6 indicators & 27 & $6.42 \%$ & 246 & $58.43 \%$ & 148 & $35.15 \%$ \\
\hline Knows 3-5 indicators & 19 & $2.29 \%$ & 322 & $38.89 \%$ & 487 & $58.82 \%$ \\
\hline Knows $1-2$ indicators & 2 & $2.13 \%$ & 25 & $26.60 \%$ & 67 & $71.28 \%$ \\
\hline Does not know indicators & 0 & $0.00 \%$ & 6 & $26.09 \%$ & 17 & $73.91 \%$ \\
\hline Behavioral patterns within the scope of body hygiene: & \multicolumn{6}{|c|}{ Chi^$^{\wedge}$ Pearsona: $76,6258, d f=6, p<0,00001$} \\
\hline Washes the whole body every day & 32 & $6.8 \%$ & 249 & $53.0 \%$ & 189 & $40.2 \%$ \\
\hline Washes the whole body several times a week & 9 & $2.1 \%$ & 197 & $46.8 \%$ & 215 & $51.1 \%$ \\
\hline Washes the whole body once a week & 7 & $1.6 \%$ & 142 & $32.9 \%$ & 283 & $65.5 \%$ \\
\hline Washes the whole body less often than once a week & 0 & $0.0 \%$ & 9 & $26.5 \%$ & 25 & $73.5 \%$ \\
\hline Behavioral patterns within the scope of oral hygiene: & \multicolumn{6}{|c|}{ Chi^2 Pearsona: $72,2590, d f=6, p<0,00001$} \\
\hline Cleans the teeth at least twice a day & 31 & $5.2 \%$ & 318 & $53.4 \%$ & 247 & $41.4 \%$ \\
\hline Cleans the teeth once a day & 14 & $2.6 \%$ & 218 & $41.1 \%$ & 299 & $56.3 \%$ \\
\hline Performs oral hygienic behaviours several times a week & 0 & $0.0 \%$ & 30 & $31.9 \%$ & 64 & $68.1 \%$ \\
\hline Never performs any oral hygienic behaviours & 2 & $1.6 \%$ & 29 & $22.8 \%$ & 96 & $75.6 \%$ \\
\hline $\begin{array}{l}\text { Behavioral patterns within the scope of self-control and treatment } \\
\text { modification: }\end{array}$ & \multicolumn{6}{|c|}{ Chi^2 Pearsona: 103,721, df=6, $p<0,00001$} \\
\hline checks blood glucose level & 26 & $10.9 \%$ & 144 & $60.2 \%$ & 69 & $28.9 \%$ \\
\hline Does not modify treatment but regularly checks blood glucose level & 7 & $3.1 \%$ & 99 & $44.4 \%$ & 117 & $52.5 \%$ \\
\hline Does not modify treatment and does not check blood glucose level & 9 & $1.2 \%$ & 277 & $37.9 \%$ & 445 & $60.9 \%$ \\
\hline Does not check blood glucose level but modifies treatment & 6 & $3.5 \%$ & 79 & $45.6 \%$ & 88 & $50.9 \%$ \\
\hline Behavioral patterns within the scope of self-observation: & \multicolumn{6}{|c|}{ Chi^2 Pearsona: $18,2269, d f=6,(p<0,05)$} \\
\hline Performs regular observations of feet and oral cavity & 34 & $4.6 \%$ & 356 & $47.6 \%$ & 357 & $47.8 \%$ \\
\hline Performs regular observations of feet and irregular observations of oral cavity & 4 & $2.3 \%$ & 69 & $39.0 \%$ & 104 & $58.7 \%$ \\
\hline Performs irregular observations of feet and oral cavity & 7 & $2.2 \%$ & 120 & $38.5 \%$ & 185 & $59.3 \%$ \\
\hline Does not perform self-observation of feet and oral cavity & 3 & $2.3 \%$ & 54 & $41.5 \%$ & 73 & $56.2 \%$ \\
\hline Patients' physical activity: & \multicolumn{6}{|c|}{ Chi^2 Pearsona: $18,2440, d f=6,(p<0,05)$} \\
\hline Regular activity, active recreation & 16 & $4.19 \%$ & 198 & $51.83 \%$ & 168 & $43.98 \%$ \\
\hline Regular activity, passive recreation & 5 & $3.85 \%$ & 52 & $40.00 \%$ & 73 & $56.15 \%$ \\
\hline Irregular activity, passive recreation & 11 & $2.63 \%$ & 182 & $43.44 \%$ & 226 & $53.94 \%$ \\
\hline Lack of activity or excessive effort & 16 & $3.74 \%$ & 165 & $38.55 \%$ & 247 & $57.71 \%$ \\
\hline Eating behaviours: & \multicolumn{6}{|c|}{ Chi^2 Pearsona: $39,9864, d f=4, p<0,00001$} \\
\hline Single dietetic errors (1-3) & 15 & $8.57 \%$ & 97 & $55.43 \%$ & 63 & $36.00 \%$ \\
\hline Many dietetic errors (4-7) & 30 & $3.54 \%$ & 370 & $43.63 \%$ & 448 & $52.83 \%$ \\
\hline Numerous dietetic errors (8 and above) & 3 & $0.88 \%$ & 132 & $38.71 \%$ & 206 & $60.41 \%$ \\
\hline Patients' care of feet hygiene: & \multicolumn{6}{|c|}{ Chi^2 Pearsona: $47,9152, d f=4, p<0,00001$} \\
\hline Lack or single disturbances & 34 & $5.82 \%$ & 299 & $51.20 \%$ & 251 & $42.98 \%$ \\
\hline Numerous disturbances & 12 & $1.85 \%$ & 259 & $39.85 \%$ & 379 & $58.30 \%$ \\
\hline Very numerous disturbances & 2 & $1.56 \%$ & 41 & $32.03 \%$ & 85 & $66.41 \%$ \\
\hline
\end{tabular}

$\mathrm{p}$ - level of significance; $\mathrm{df}$ — number of degrees of freedom; Chi^2 Pearsona — Pearson's chi-squared test

Table 6: The level of family's knowledge about the disease and patient's knowledge and behaviours. 
Citation: Abramczyk A (2013) The Family Knowledge about the Disease and Complications Risk among Diabetic Patients-in Poland. J Data Mining Genomics Proteomics 4: 142. doi:10.4172/2153-0602.1000142

Page 6 of 9

\begin{tabular}{|c|c|c|c|c|c|c|}
\hline \multirow{2}{*}{\begin{tabular}{|l|} 
Tested feature \\
Total $\mathrm{N}=1366$ \\
\end{tabular}} & \multicolumn{6}{|c|}{ The level of family's knowledge about the disease: } \\
\hline & \multicolumn{2}{|c|}{$\begin{array}{c}\text { Moderate } \\
\begin{array}{c}\text { (20,0-13,5 points) } \\
\mathrm{N}=48 \\
3,5 \%\end{array}\end{array}$} & \multicolumn{2}{|c|}{$\begin{array}{c}\text { Minimal } \\
(13,0-6,5 \text { points }) \\
N=599 \\
43,9 \%\end{array}$} & \multicolumn{2}{|c|}{$\begin{array}{c}\text { None } \\
\text { (6-0 points) } \\
N=719 \\
52,6 \%\end{array}$} \\
\hline BMI: & \multicolumn{6}{|c|}{ Chi^2 Pearsona: 28,6596, df=6, p<0,0005 } \\
\hline Normal weight BMI: $(\mathrm{M}<24,9 ; \mathrm{W}<23,9)$ & 11 & $5.9 \%$ & 100 & $53.5 \%$ & 76 & $40.6 \%$ \\
\hline Overweight, BMI: (M=25-29,9; W=24-29,9) & 21 & $4.3 \%$ & 222 & $45.3 \%$ & 247 & $50.4 \%$ \\
\hline Obesity, BMI: (30-40) & 14 & $2.4 \%$ & 245 & $41.8 \%$ & 327 & $55.8 \%$ \\
\hline Giant obesity, BMI: (>40) & 1 & $1.2 \%$ & 24 & $28.2 \%$ & 60 & $70.6 \%$ \\
\hline WHR: & \multicolumn{6}{|c|}{ Chi^2 Pearsona: $18,6279, d f=4, p<0,005$} \\
\hline Type $A O(M>=1 ; W=>0,85)$ & 15 & $2.3 \%$ & 272 & $41.1 \%$ & 375 & $56.6 \%$ \\
\hline Type GO $(M<1 ; W<0,85)$ & 18 & $4.0 \%$ & 194 & $43.4 \%$ & 235 & $52.6 \%$ \\
\hline Does not apply WHR & 11 & $5.9 \%$ & 100 & $53.5 \%$ & 76 & $40.6 \%$ \\
\hline $\begin{array}{l}\text { Waist circumference and a risk of metabolic complications (waist circumfer- } \\
\text { ence in men }>94 \mathrm{~cm} \text { and in women }>80 \mathrm{~cm} \text {, with } \mathrm{BMI}>25 \text { ): }\end{array}$ & \multicolumn{6}{|c|}{ Chi^2 Pearsona: $23,3133, \mathrm{df}=2, \mathrm{p}<0,00005$} \\
\hline Increased & 25 & $2.4 \%$ & 426 & $41.8 \%$ & 569 & $55.8 \%$ \\
\hline Normal & 19 & $6.4 \%$ & 151 & $51.2 \%$ & 125 & $42.4 \%$ \\
\hline Blood pressure $[\mathrm{mm} / \mathrm{Hg}]$ : & \multicolumn{6}{|c|}{ Chi^$^{\wedge}$ Pearsona: $28,4760, d f=6, p<0,005$} \\
\hline$(<120-130$ and $<80-85)$ & 15 & $7.9 \%$ & 78 & $41.0 \%$ & 97 & $51.1 \%$ \\
\hline$(130-139$ and $85-89)$ & 8 & $5.2 \%$ & 71 & $46.4 \%$ & 74 & $48.4 \%$ \\
\hline$(140-159$ and $90-99)$ & 18 & $3.4 \%$ & 257 & $47.9 \%$ & 261 & $48.7 \%$ \\
\hline$(>160-179 / 100-109$ and $>=180 />100)$ & 7 & $1.5 \%$ & 187 & $39.2 \%$ & 283 & $59.3 \%$ \\
\hline Triglycerides [mg/dl]: & \multicolumn{6}{|c|}{ Chi^2 Pearsona: $13,1950, d f=4, p<0,05$} \\
\hline$<150 \mathrm{mg} / \mathrm{dl}$ & 16 & $7.6 \%$ & 88 & $41.7 \%$ & 107 & $50.7 \%$ \\
\hline $150-200 \mathrm{mg} / \mathrm{dl}$ & 1 & $0.5 \%$ & 82 & $44.6 \%$ & 101 & $54.9 \%$ \\
\hline$>200 \mathrm{mg} / \mathrm{dl}$ & 4 & $3.0 \%$ & 58 & $43.6 \%$ & 71 & $53.4 \%$ \\
\hline Physical fitness: & \multicolumn{6}{|c|}{ Chi^2 Pearsona: $49,0203, d f=6, p<0,00001$} \\
\hline Physically fit (7 points) & 10 & $8.2 \%$ & 70 & $57.9 \%$ & 41 & $33.9 \%$ \\
\hline Few limitations of physical ability (8-14 points) & 24 & $3.8 \%$ & 298 & $47.2 \%$ & 310 & $49.0 \%$ \\
\hline Many limitations of physical ability (in at least one factor) (15-21 points) & 13 & $2.4 \%$ & 189 & $35.3 \%$ & 334 & $62.3 \%$ \\
\hline Lack of physical ability in at least one factor (22-28 points) & 1 & $1.3 \%$ & 42 & $54.5 \%$ & 34 & $44.2 \%$ \\
\hline Independence: & \multicolumn{6}{|c|}{ Chi^2 Pearsona: $50,7848, \mathrm{df}=6, \mathrm{p}<0,00001$} \\
\hline Fully independent & 15 & $8.2 \%$ & 104 & $56.8 \%$ & 64 & $35.0 \%$ \\
\hline Insignificant limitations of independence & 21 & $4.2 \%$ & 232 & $46.7 \%$ & 244 & $49.1 \%$ \\
\hline $\begin{array}{l}\text { Marked limitations of independence (partially unable to perform a minimum } \\
\text { of } 1 \text { activity) }\end{array}$ & 12 & $1.9 \%$ & 237 & $37.9 \%$ & 376 & $60.2 \%$ \\
\hline No independence (totally unable to perform a minimum of 10 activity) & 0 & $0.0 \%$ & 26 & $42.6 \%$ & 35 & $57.4 \%$ \\
\hline Somatic ailments: & \multicolumn{6}{|c|}{ Chi^2 Pearsona: $17,0339, \mathrm{df}=4, \mathrm{p}<0,005$} \\
\hline None & 34 & $4.0 \%$ & 407 & $47.7 \%$ & 413 & $48.3 \%$ \\
\hline Single (1-2) & 12 & $2.9 \%$ & 155 & $37.2 \%$ & 249 & $59.9 \%$ \\
\hline Many (3 and more) & 2 & $2.1 \%$ & 37 & $38.5 \%$ & 57 & $59.4 \%$ \\
\hline Disturbances and symptoms in the psycho-emotional life & \multicolumn{6}{|c|}{ Chi^2 Pearsona: $22,7602, d f=6, p<0,005$} \\
\hline No ailments & 29 & $4.5 \%$ & 310 & $48.1 \%$ & 306 & $47.4 \%$ \\
\hline 1-2 ailments & 9 & $2.0 \%$ & 170 & $37.2 \%$ & 278 & $60.8 \%$ \\
\hline 3-4 ailments & 4 & $2.9 \%$ & 63 & $46.0 \%$ & 70 & $51.1 \%$ \\
\hline 5 and more ailments & 5 & $5.7 \%$ & 37 & $42.0 \%$ & 46 & $52.3 \%$ \\
\hline Concomitant diseases: & \multicolumn{6}{|c|}{ Chi^2 Pearsona: $22,3669, \mathrm{df}=6, \mathrm{p}<0,005$} \\
\hline No diagnosis of concomitant diseases & 10 & $6.7 \%$ & 82 & $54.6 \%$ & 58 & $38.7 \%$ \\
\hline 1-2 concomitant diseases & 25 & $4.2 \%$ & 250 & $41.7 \%$ & 325 & $54.1 \%$ \\
\hline 3-4 concomitant diseases & 7 & $1.7 \%$ & 172 & $41.4 \%$ & 236 & $56.9 \%$ \\
\hline 5 and more concomitant diseases & 6 & $3.0 \%$ & 95 & $47.2 \%$ & 100 & $49.8 \%$ \\
\hline
\end{tabular}

Table 7: The level of family's knowledge about the disease and selected health indicators in diabetes patients. 


\begin{tabular}{|c|c|c|c|c|c|c|}
\hline Tested feature & \multicolumn{6}{|c|}{ The level of family's knowledge about the disease: } \\
\hline Total $\mathrm{N}=1366$ & \multicolumn{2}{|c|}{$\begin{array}{c}\text { Moderate } \\
(20,0-13,5 \text { points }) \\
N=48 \\
3,5 \%\end{array}$} & \multicolumn{2}{|c|}{$\begin{array}{c}\text { Minimal } \\
(13,0-6,5 \text { points }) \\
N=599 \\
43,9 \%\end{array}$} & \multicolumn{2}{|c|}{$\begin{array}{c}\text { None } \\
\text { (6-0 points) } \\
N=719 \\
52,6 \%\end{array}$} \\
\hline $\begin{array}{l}\text { Patients' difficulty in respecting of } \\
\text { recommendations: }\end{array}$ & \multicolumn{5}{|c|}{ Chi^2 Pearsona: $18,9759, \mathrm{df}=6,(\mathrm{p}<0,005)$} & \\
\hline No difficulties & 35 & $4.6 \%$ & 338 & $44.5 \%$ & 387 & $50.9 \%$ \\
\hline 1-2 difficulties & 10 & $3.2 \%$ & 152 & $48.6 \%$ & 151 & $48.2 \%$ \\
\hline 3-4 difficulties & 2 & $1.7 \%$ & 44 & $37.6 \%$ & 71 & $60.7 \%$ \\
\hline 5 and more difficulties & 1 & $0.6 \%$ & 65 & $36.9 \%$ & 110 & $62.5 \%$ \\
\hline Social situation and living conditions: & \multicolumn{6}{|c|}{ Chi^2 Pearsona: $30,8129, \mathrm{df}=2, \mathrm{p}<0,00001$} \\
\hline Very good and sufficient & 38 & $5.0 \%$ & 370 & $48.4 \%$ & 356 & $46.6 \%$ \\
\hline Insufficient and none & 10 & $1.7 \%$ & 229 & $38.0 \%$ & 363 & $60.3 \%$ \\
\hline Difficulties of patients in access to medical services: & \multicolumn{6}{|c|}{ Chi^2 Pearsona: $10,6027, d f=4, p<0,05$} \\
\hline No difficulties & 6 & $4.0 \%$ & 81 & $54.4 \%$ & 62 & $41.6 \%$ \\
\hline Problems with access to $1-3$ services & 33 & $4.2 \%$ & 365 & $46.9 \%$ & 381 & $48.9 \%$ \\
\hline Problems with access to 4 or to all the services & 6 & $2.8 \%$ & 84 & $39.1 \%$ & 125 & $58.1 \%$ \\
\hline Need for professional care: & \multicolumn{6}{|c|}{ Chi^2 Pearsona: $106,492, d f=2, p<0,00001$} \\
\hline Moderate & 31 & $7.3 \%$ & 253 & $59.8 \%$ & 139 & $32.9 \%$ \\
\hline High and very high & 17 & $1.8 \%$ & 346 & $36.7 \%$ & 580 & $61.5 \%$ \\
\hline
\end{tabular}

Table 8: The level of family's knowledge about the disease and difficulties in respecting recommendations, difficulties in access to medical services, social situation and need for care in diabetes patients.

fitness and independency, no emotional or somatic problems and no accompanying diseases which require treatment.

The deficit of the recommended behaviours, excessively low indicators of health, incidence of accompanying diseases, higher risk of complications and the high demand for professional health care, as observed in patients whose families lack the knowledge about diabetes, confirm the opinion that the sole fact of having a family is not enough to ensure better care for diabetes patients and that families not always support patients [29]. Such results could be demonstrating that the high deficit of the knowledge about diabetes among both patients and their supporting families could lead to negative clinical effects [33]. Own studies confirmed the correlation of the level of knowledge in the patient's family with the health and the risk of complications $[29,45,48]$.

The studies demonstrated that professional and comprehensive education of families and caregivers who support diabetes patients at home is a measure preventing the risk of errors in patient care [49] and promoting better implementation of medical recommendations [50]. The education of patient families helps to improve their competences, effective care and nursing and involvement in the basic and secondary prevention of diabetes. It also leads to better results in patient care, followed by the reduction of costs of such care [36,47]. In our study, those patients who had families with better knowledge of diabetes more frequently behaved as recommended in the treatment of diabetes and had the indicators of personal health closer to the standard levels, including body mass, blood pressure, triglycerides, full physical fitness and self-reliance, no emotional or somatic problems and no accompanying diseases which require treatment. Such situation could result from more effective procedures which the families with better knowledge apply, and provides grounds for including family training as the permanent component of high-quality health care rather than just a solution dedicated to families of old-age patients or patients with serious deficits (as is the case in the Polish health care system) [27]. The incidence of diabetes is rising and the costs of health care are high but the Polish system still lacks a diabetes-dedicated register or incentives to commit the state to diabetes prevention and related training [27].
The conducted studies are a frontier research. Many positive results of patient care which is rendered by patient families with better knowledge about diabetes, and the great deficit of such knowledge among many families, as demonstrated by the studies, are a crucial but underestimated factor in the care of diabetes patients, while such care provided by supportive families could lead to reduced incidence of complications and lower costs of treatment.

\section{Study reservations}

1. Study results cover patients and families from those PHC facilities only where the doctors and nurses agreed to participate in the study.

2. The study cannot be completed, if the doctor, the nurse and the patient do not cooperate.

\section{The study does not involve a longer observation.}

4. $n$ their medical history, some patients lack results of biomechanical tests (triglycerides), anthropometrics and body mass information.

5. he missing results could explain why there is no connection between the knowledge of diabetes among families and the medical indicators of treatment (such as $\mathrm{HbAlc}$ ).

\section{Conclusions}

1. Family knowledge about the disease is a significant factor that diversifies a medical condition of diabetic patients.

2. Higher knowledge level of the family about the disease improves patients' medical condition and reduces the risk of diabetes complications.

3. The process of preventing diabetes complications in this group of patients should reflect the impact from the level of knowledge about diabetes among supporting families.

\section{Acknowledgement}

This study was carried out within the scope of SCSR grant no 6P05D02320 directed by the author of this paper. 
Citation: Abramczyk A (2013) The Family Knowledge about the Disease and Complications Risk among Diabetic Patients-in Poland. J Data Mining Genomics Proteomics 4: 142. doi:10.4172/2153-0602.1000142

\section{Questions evaluating the knowledge of the disease:}

In your opinion, diabetes is a illness where:

1 -there is too much insulin

2-there is too little insulin

3-I don't know

What leads to high blood sugar?

What leads to low blood sugar?

What is hypoglycemia?

What are the symptoms of low blood sugar (hypoglycemia)?

What are the symptoms of high blood sugar (hyperglycemia)?

What are the symptoms of ketotic coma?

What are the complications in diabetes?

What supports normal glucose level in blood?

What reduces the risk of complications in diabetes?

How to perform foot care in diabetes?

What the diabetes patient should control himself/herself?

What are the rules of nutrition in diabetes?

What are the physical activity recommendations in diabetes?

What are the effects using drugs for diabetes?

1-lower blood sugar level

2-higher blood sugar level

3-no effect on the blood sugar level

4-I don't know their role or effects

What is the objective of the diet (nutrition) in diabetes?

What are the effects of physical activity in diabetes?

1-lower blood sugar level

2-higher blood sugar level

3-no effect on the blood sugar level

4-I don't know its role or effects

What are the effects of Glucagon?

1-higher blood sugar level

2-lower blood sugar level

3-no effect on the blood sugar level

4-I don't know its role or effects

What is the recommended procedure with low blood sugar (hypoglycemia)?

1-eat an extra meal

2-wait until the condition passes

3-skip one meal

4-take an extra dose of the drug

5-I don't know

What is the recommended procedure with high blood sugar (hyperglycemia)?

When to perform urine tests for acetone?

How to prevent hypoglycaemia? How to prevent hyperglycaemia?

Table 9: Questions evaluating the knowledge of the disease.

\section{References}

1. Wild S, Roglic G, Green A, Sicree R, King H (2004) Global Prevalence of diabetes: estimates for the year 2000 and projections for 2030. Diabetes Care 27: 1047-1053

2. King H, Aubert RE, Herman WH (1998) Global burden of diabetes, 1995-2025: prevalence, numerical estimates, and projections. Diabetes Care 21: 14141431.

3. Zimmet P, Alberti KG, Shaw J (2001) Global and societal implications of the diabetes epidemic. Nature $414: 782-78$.

4. International Diabetes Federation (2012) IDF, Diabetes Atlas (5thedn).

5. Morrish NJ, Wang SL, Stevens LK, Fuller JH, Keen H (2001) Mortality and causes of death in the WHO Multinational Study of Vascular Disease in Diabetes. Diabetologia 2: 14-21.

6. Global data on visual impairments 2010 (2012) World Health Organization, Geneva, Switzerland
7. Global status report on noncommunicable diseases 2010 (2011) World Health Organization, Geneva, Switzerland

8. Morgan CL, Currie CJ, Peters JR (2000) Relationship between diabetes and mortality: a population study using record linkage. Diabetes Care 23: 11031107.

9. Decline in deaths from heart disease and stroke-United States 1900-1999 (1999) MMWR Morb Mortal Wkly Rep 48: 649-656.

10. Donnelly R, Emslie-Smith AM, Gardner ID, Morris AD (2000) Clinical review $\mathrm{ABC}$ of arterial and venous disease Vascular complications of diabetes. BM 320: $1062-1066$

11. Woodward M, Zhang X, Barzi F, Pan W, Ueshima H, et al. (2003) The Effects of Diabetes on the Risks of Major Cardiovascular Diseases and Death in the Asia-Pacific Region. Asia Pacific Cohort Studies Collaboration. Diabetes Care 26: 360-366.

12. Tuomilehto J, Rastenyte D, Jousilahti P, Sarti C, Vartiainen E (1996) Diabetes Mellitus as a Risk Factor for Death From Stroke. Prospektive Study of the Middle-aged Finnish Population. Stroke 27: 210-215.

13. Lehto S, Ronnemaa T, Pyorala K, Laakso M (1996) Predictors of Stroke In Middle- Aged Patients With Non-Insulin-Dependent Diabetes. Stroke 27: 63-68.

14. Kropiwnicka A, Drzewoski J (2001) Udary mózgu u chorych na cukrzycę. Diab Prakt 2: 183-189.

15. Domżał T (1999) Epidemiologia udarów mózgu. Niedokrwienne udary mózgu. (red.) Prusiński A, a-medica press. Bielsko-Biała; 25-30.

16. Tatoń J, Jamiołowska E (2001) Choroby narządu wzroku powodowane przez cukrzycę. Diabetologia. (red.) Tatoń J, Czech A. PZWL, Warszawa; t. 2: 80-119.

17. Geiss LS, Herman WH, Teutsch SM (1985) Diabetes and renal mortality in the United States . Am J Public Health 75: 1325-1326.

18. Rothman AA, Wagner EH (2003) Chronic Illness Management: What Is the Role of Primary Care? Ann Intern Med 138: 256-261.

19. Ritz E, Rychlik I, Locatelli F, Halimi S (1999) End-stage renal failure in type 2 diabetes: A medical catastrophe of worldwide dimensions. Am J Kidney Dis 34: 795-808.

20. Kiberd BA, Jindal KK (1995) Screening to prevent renal failure in insulin dependent diabetic patients: an economic evaluation BMJ 311: 1595-1599.

21. Muller IS, de Grauw WJC, van Gerwen WHEM, Bartelink ML, van den Hoogen HJM, et al. (2002) Foot Ulceration and Lower Limb Amputation in Type 2 Diabetic Patients in Dutch Primary Health Care. Diabetes Care 25: 570-574.

22. Lavery LA, Lavery DC, Quebedeax-Farnham TL (1995) Increased foot pressures after great toe amputation in diabetes. Diabetes Care 18: 1460-1462.

23. O'Brien IA, McFadden JP, Corrall RJ (1991) The influence of autonomic neuropathy on mortality In insulin-dependent diabetes. Q J Med 79: 495-502.

24. Vinik Al, Maser RE, Mitchell BD, Freeman R (2003) Diabetic Autonomic Neuropathy. Diabetes Care 26: 1553-1579.

25. Mathers CD, Loncar D (2006) Projections of global mortality and burden of disease from 2002 to 2030 . PLoS Med 3.

26. Roglic G, Unwin N, Bennett PH, Mathers C, Tuomilehto J, et al. (2005) The burden of mortality attributable to diabetes: realistic estimates for the year 2000. Diabetes Care 28: 2130-2135.

27. FEND, EURADIA, PCDE, IDF. Diabetes. The Policy Puzzle: Is Europe Making Progress? Third edition.

28. Von Korff M, Gruman J, Schaefer J, Curry SJ, Wagner EH (1997) Collaborative Management of Chronic Illness. Ann Intern Med 127: 1097-1102.

29. Mayberry LS, Osborn CY (2012) Family support, medication adherence, and glycemic control among adults with type 2 diabetes. Diabetes Care 35: 1239 1245.

30. Abramczyk A, Łopatyński J (2002) Udział rodziny w realizacji opieki nad chorym z cukrzyca. Cukrzyca-problem społeczny. Abramczyk A, Łopatyński J. Prusek W, AM, Wrocław.

31. Glasgow RE, Toobert DJ (1988) Social environment and regimen adherence among type II diabetic patients. Diabetes Care 11: 377-386.

32. Gentili P, Maldonato A, Grieco R, Santini A (2001) Influence of patient's 
Citation: Abramczyk A (2013) The Family Knowledge about the Disease and Complications Risk among Diabetic Patients-in Poland. J Data Mining Genomics Proteomics 4: 142. doi:10.4172/2153-0602.1000142

representations and beliefs about diabetes and is treatment on their adherence to therapy. Diabetes Nutr Metab 14: 140-152.

33. Reason JS, American College of Endocrinology, American Association of Clinical Endocrinologists (2005) Patient Safety and Medical System Errors in Diabetes and Endocrinology Consensus. Conference Washington DC, USA.

34. Hellman R, Hellman J, Rosen H (1999) Provider error is an important cause of poor outcomes in diabetes care. Diabetes. 48: A67.

35. Kuo YF, Raji MA, Markides KS, Ray LA, Espino DV, et al. (2003) Inconsistent Use of Diabetes Medications, Diabetes Complications, and Mortality in Olde Mexican Americans Over a 7-Year Period: Data from the Hispanic Established Population for the Epidemiologic Study of the Elderly. Diabetes Care 26: 3054 3060.

36. Abramczyk A (2010) Towarzyszace cukrzycy stany chorobowe a sytuacja chorych na cukrzycę. Interdyscyplinarne aspekty nauk o zdrowiu. Dębska G Jaśkiewicz J; Krakowskie Towarzystwo Edukacyjne sp. z o.o. -Oficyna Wydawnicza AFM; Kraków.

37. Abramczyk A (2007) Impact of family situation of patients with diabetes on their expectations towards care provided by the community/family nurse. Pol.J.Environ.Stud. 16 no. 6D: 166-168.

38. Abramczyk A (2007) Stan opieki nad chorym z cukrzycą w podstawowej opiece zdrowotnej a zapotrzebowanie na opiekę pielęgniarską. AM Wrocław.

39. sobczyk M : Statystyka (1997) PWN. Warszawa.

40. Brzeziński J (2003) Metodologia badań psychologicznych. PWN, Warszawa 231-248
41. Juszczyk S (2002) Statystyka dla Pedagogów. Toruń; 59-65.

42. Abramczyk A (2012) Results of specialized ambulatory diabetes care among diabetes patients at the level of primary health care in the light of nationwide research. Adv Clin Exp Med 21: 63-68.

43. Abramczyk A (2009) How does sex differentiate the situation of diabetic patients -in the light of nationwide research. Clin Exp Med Lett 50: 99-105.

44. Abramczyk A (2009) Selected aspects of functioning of the primary health care system in opinion of patients with diabetes - in the light of nationwide research. Clin Exp Med Lett 50: 11-18.

45. Arora S, Marzec K, Gates C, Menchine M (2011) Diabetes knowledge in predominantly Latino patients and family caregivers in an urban emergency department. Ethn Dis 21: 1-6.

46. Ahmad MA, Shenouda MS, Mohammed MD (2012) "Knowledge and Practices of Juvenile Diabetes' Caregivers at Home-in Minia University Hospital”, The Medical Journal of Cairo University.

47. Sahoo S, Brahma PK, Mohapatra PK (2010) BURDEN OF CAREGIVER'S AMONG THE MENTALLY ILL AND DIABETIC PATIENTS - A COMPARATIVE STUDY, The Orissa Journal of Psychiatry 39-47.

48. Garcia-Huidobro G, Bittner M, Brahm P, Puschel K (2011) Family intervention to control type 2 diabetes: a controlled clinical trial. Fam Pract 28: 4-11.

49. Hellman R (2001) Improving Patient Safety in Diabetes Care: The Importance of Reducing Medical Errors. Clinical Diabetes 19: 190-192.

50. Whitford DL, McGee H, O'Sullivan B (2009) Will People With Type 2 Diabetes Speak to Family Members About Health Risk? Diabetes Care 32: 251-253. 